\title{
EFFECT OF HEAT TREATMENT OF AUSTENITIC CAST IRON (NI- RESIST) ON WEAR AND CORROSION RESISTANCE
}

\author{
Tarmono $^{1}$, Nugroho Santoso ${ }^{2}$, Lilik Dwi Setyana ${ }^{3}$ \\ ${ }^{I}$ Mechanical Engineering Department, Vocational College, Universitas Gadjah Mada, Indonesia \\ ${ }^{2}$ Mechanical Engineering Department, Vocational College, Universitas Gadjah Mada, Indonesia \\ ${ }^{3}$ Mechanical Engineering Department, Vocational College, Universitas Gadjah Mada, Indonesia
}

\begin{abstract}
Austenitic Cast Iron (Ni-Resist) is widely used for products with wear and corrosion resistance. The wear and corrosion resistance can be improved by heat treatment so that it has longer lifetime. The purpose of this research is to find out the appropriate heat treatment so that wear and corrosion resistance is optimal.Heat treatment is carried out normalizing, quenching and tempering $\left(200^{\circ} \mathrm{C}\right.$ and $\left.400^{\circ} \mathrm{C}\right)$ on austenitic cast iron with the main alloy $17 \% \mathrm{Ni} ; 3,06 \% \mathrm{C} ; 2,77 \% \mathrm{Si}$ and $2,13 \% \mathrm{Cr}$. The formation of austenite structures can improve wear and corrosion resistance. Tests carried out include wear resistance, corrosion resistance and micro analysis in as-cast and after heat treatment.The wear rate of the as cast is $1,34 E-4 \mathrm{~mm} / \mathrm{kg} . \mathrm{m} . \mathrm{Heat}$ treatment increases wear resistance by $31 \%$ (normalizing), $63 \%$ (quenching), $88 \%$ (tempering $200^{\circ}$ C) and $75 \%$ (tempering $400^{\circ} \mathrm{C}$ ) compared to as cast. The corrosion rate of the as cast is 9,15E-5 mpy. Heat treatment decreases corrosion rate by $38 \%$ (normalizing), $52 \%$ (quenching), $29 \%$ (tempering $200^{\circ} \mathrm{C}$ ) and $14 \%$ (tempering $400^{\circ} \mathrm{C}$ ) compared to as cast. Increased wear and corrosion resistance occur due to changes in microstructure and graphite size.
\end{abstract}

Keywords: - heat treatment, austenitic cast iron, corrosion, wear

\section{INTRODUCTION}

Corrosion and wear is the source of damage to some equipment in the industry, especially equipment that works in aggressive environments. Materials that have high corrosion resistance and wear resistance are needed. Water pump impeller products made from austenitic cast iron (NiResist) must have high wear resistance to increase their service life. Ni-Resist is cast iron with the main alloy nickel with the content of 12 until 34\% [1]. Cast products with $\mathrm{Ni}$ alloy $>16 \%$ have austenitic microstructure with stability increasing with increasing nickel [2].

The impeller product produced has low wear resistance (short service life) because the austenite structure has not been formed evenly. The austenite structure will become more stable and evenly distributed if it has the right nickel content or heat treatment. During cooling during heat treatment, partial transformation of austenite to martensite occurs, resulting in higher wear resistance. The austenitic structure that makes structural stability to occur during cooling is due to a decrease in the level of carbon diffusion in austenites [3]. Single phase alloy matrices are usually more corrosion resistant than multi-phase matrices [2]. Microstructure consisting of a mixture of austenite and martensite will increase the service life of components from cast iron [4].

\section{LITERATURE REVIEW}

$\mathrm{Ni}-$ Resist is cast iron with the main alloy nickel $(34 \% \mathrm{Ni})$ as a form of austenite structure that has superior properties. $\mathrm{Ni}$-Resist is widely used for equipment with heat resistance, corrosion and wear. Ni-Resist is divided into two groups: flake and spheroidal graphite alloys. The elements of copper and magnesia help to form spheroidal graphite in the Ni-resist ductile. The chemical composition required is carbon, silicon, mangaan, nickel, chromium, sulfur, and molybdenum [5].

Ni-Resist is a high alloy material with single phase matrix which has high corrosion resistance [1]. Very high nickel content can be reduced by manganese and copper to obtain austenitic Ni-Mn-Cu cast iron with corrosion resistance similar to Ni-Resist [6].

Ni-Resist alloys with high nickel content cause partial transformation of austenite to martensite, which significantly increases hardness resulting in high abrasive resistance. At higher levels of austenitic transformation, abrasive wear resistance is increasing. Corrosion resistance is determined by the composition of nickel [2].

Ni-resist has a stable structure [7]. The microstructure of $\mathrm{Ni}-\mathrm{Mn}-\mathrm{Cu}$ cast iron will be in the form of austenite if the nickel is at least $16 \%$ equivalent. The hardness of EquNi castings products is more than $16 \%$ relatively low, ranging from 100 to $140 \mathrm{HB}$. The hardness increases to 400 to 460 $\mathrm{HB}$ with the smallest minimum nickel value as shown in Figure 1 [8]. 


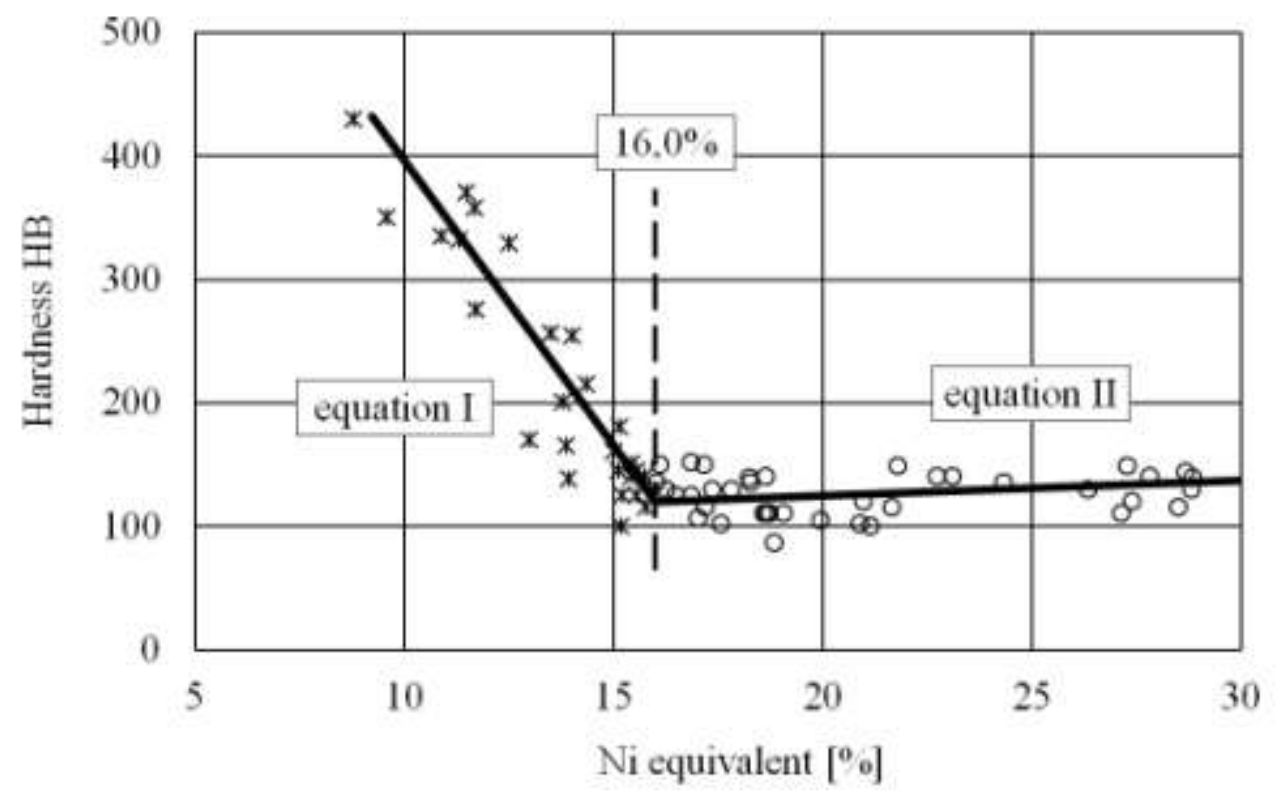

Fig 1: The effect of Ni equivalent to hardness in austenitic cast iron

The use of cast iron with high nickel content is expensive, so austenitic cast iron with low nickel content is developed. The nickel element is replaced by $\mathrm{Mn}$ and controls the content of $\mathrm{Cu}, \mathrm{Cr}$ and $\mathrm{Si}$. The corrosion resistance of low nickel austenitic cast iron in $5 \% \mathrm{HCl}$ solution is almost the same as high nickel austenitic cast iron [9].

Primary Austenite in cast iron is the first phase of nucleation in molten metal and grows as a dendritic structure, followed by the growth of eutectic phases. Eutectic growth continues at ranges and temperature intervals for both dendrite and eutectic growth interchangeably. This overlapping temperature interval can provide an opportunity for continued dendrite growth from primary austenite along with eutectic reactions [10]. Primary austenite grains can be seen with color etching techniques. Eutectic cell size and graphite shape are affected when freezing. Increased nucleation of austenite grains results in an increase in the number of eutectic cells [11].

The heat treatment of annealing and normalizing types is generally carried out on alloy cast iron. Normalizing austenitic cast iron material increases ductility, while annealing has no effect [12].

\section{METHODS}

Increased wear resistance is carried out with variations in heat treatment in the form of austenisation-quenching, tempering and normalizing. Austenisation is carried out at a temperature of $1050^{\circ} \mathrm{C}$ then quenching using water media. Tempering is carried out at temperatures of $200^{\circ} \mathrm{C}$ and $400^{\circ} \mathrm{C}$ for 2 hours in the furnace. The heat treatment is carried out to improve the stability of the austenitic structure so as to increase the resistance to wear resistance of pump impeller products from austenitic cast iron products. Test specimens made are wear, hardness and microstructure specimens.

\section{RESULTS AND DISCUSSIONS}

\subsection{Chemical Composition}

The testing of Ni-resist chemical composition was carried out with spectrometry with the main composition in the form of nickel $(17.56 \%)$, carbon $(3.06 \%)$, silicon $(2.77 \%)$ and chroom (2.13\%) in accordance with the ASTM A436 standard as austenitic cast iron (Ni-resist) (Table 1).

Table 1: Test results of Ni-resist chemical composition

\begin{tabular}{|l|l|l|l|l|l|}
\hline No & Element & $\begin{array}{l}\text { Amount } \\
(\%)\end{array}$ & No & Element & $\begin{array}{l}\text { Amount } \\
(\%)\end{array}$ \\
\hline 1 & $\mathrm{C}$ & 3,06 & 9 & $\mathrm{Cu}$ & 0,04 \\
\hline 2 & $\mathrm{Si}$ & 2,77 & 10 & $\mathrm{~W}$ & 0,04 \\
\hline 3 & $\mathrm{~S}$ & 0,03 & 11 & $\mathrm{Ti}$ & 0,02 \\
\hline 4 & $\mathrm{P}$ & 0,05 & 12 & $\mathrm{Sn}$ & 0,01 \\
\hline 5 & $\mathrm{Mn}$ & 1,03 & 13 & $\mathrm{Al}$ & 0,01 \\
\hline 6 & $\mathrm{Ni}$ & 17,56 & 14 & $\mathrm{Mg}$ & 0,03 \\
\hline 7 & $\mathrm{Cr}$ & 2,13 & 15 & $\mathrm{Zn}$ & 0,01 \\
\hline 8 & $\mathrm{Mo}$ & 0,01 & 16 & $\mathrm{Fe}$ & 73,14 \\
\hline
\end{tabular}

\subsection{Micro Structure}

The results of microstructure observation are graphite with austenite matrix (Figure 2). There are flake-shaped graphite with different size and spread after heat treatment. Graphite on as cast specimens is small in size with less even distribution so the austenite grain size is not the same. Graphite forms become larger with even distribution after austenisation-quenching. Temper treatment makes the size of graphite longer with tenuous distances. The higher the 
tempering of the temperature, the longer the size and the larger austenite grain is. Specimens with normalized treatment showed the largest size of graphite with even distribution.

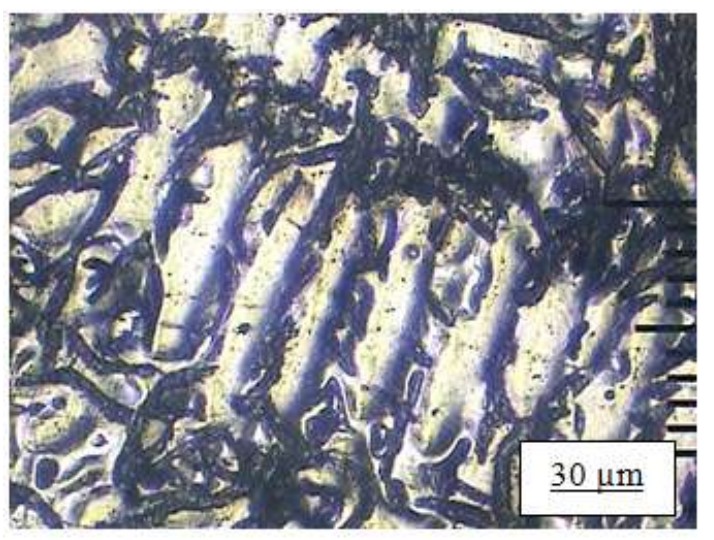

(a). As Cast

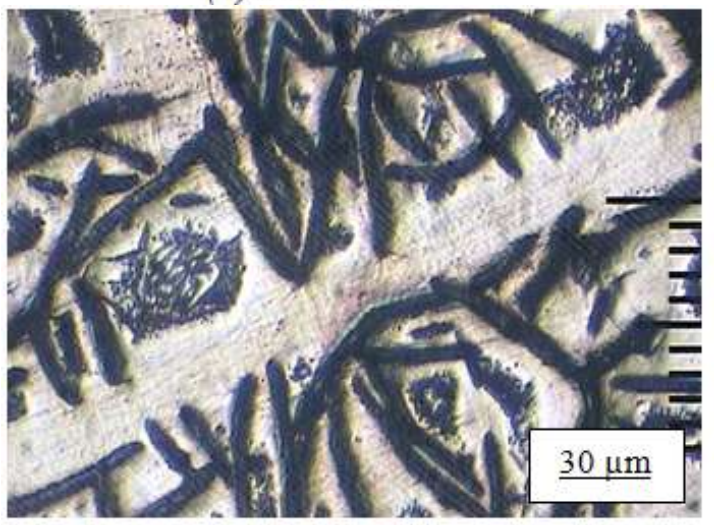

(c). Quenching

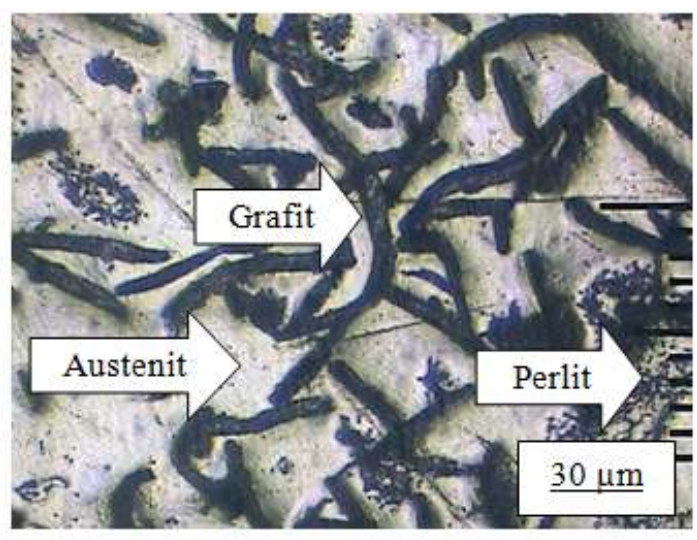

(b). Normalising

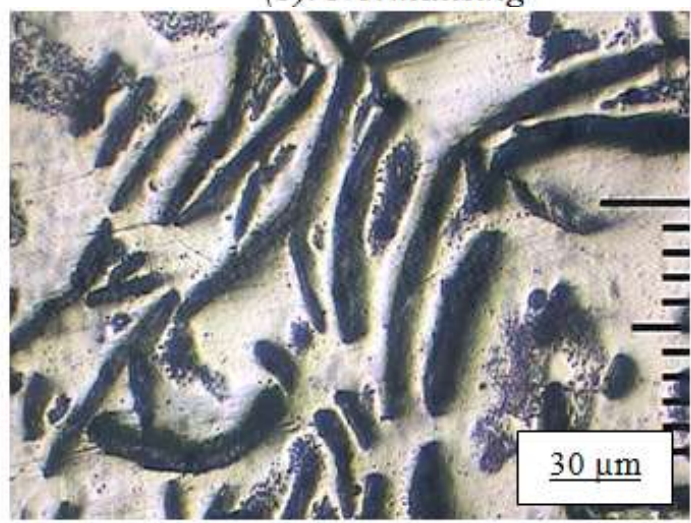

(d). Quenching-Tempering $200^{\circ} \mathrm{C}$

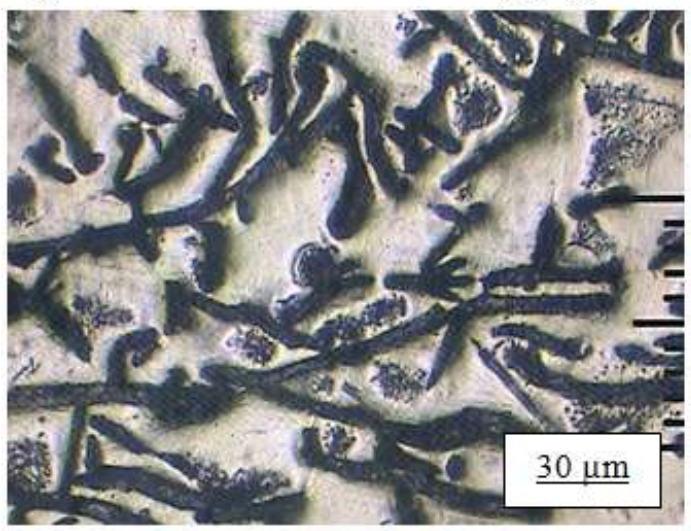

(e). Quenching-Tempering $400^{\circ} \mathrm{C}$

Fig 2: Observation results of Ni-resist microstructure

\subsection{Corrosion Testing}

Austenitic cast iron heat treatment (Ni-resist) affects the corrosion resistance (Figure 3). The corrosion rate of as cast is $9,15 \mathrm{E}-5$ mpy then decreased to 5,6E-5 mpy (an decrease of $38 \%$ ) after the normalization process. The highest decrease $(52 \%)$ occurred in quenching specimens.
Decreased corrosion rate occurs due to partial transformation of austenite to martensite [2] (Medynski and Janus, 2016). Tempering treatment decreases corrosion rate by up to $29 \%$ (temper $200^{\circ} \mathrm{C}$ ) because the structure gradually relaxes with the size of the graphite enlarging as the tempering temperature increases. 


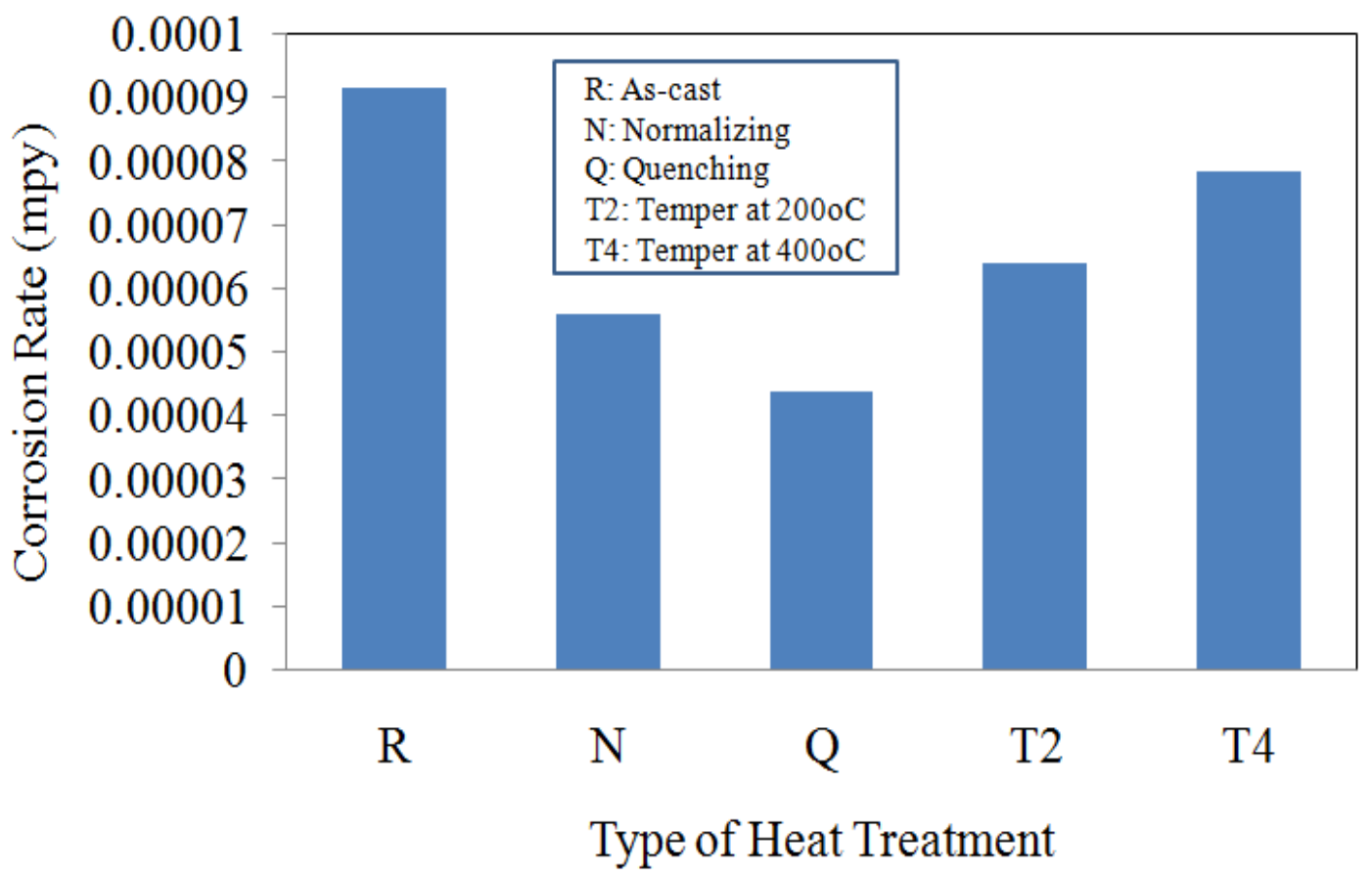

Fig 3: Corrosion Testing Result

\subsection{Wear Testing}

Ni-resist heat treatment affected its wear resistance (Figure 4) with the wear rate of the as cast product of $1,34 \mathrm{E}-4$ $\mathrm{mm}^{3} / \mathrm{kg} . \mathrm{m}$. Normalizing heat treatment can increase wear resistance by $31 \%$, and $63 \%$ after quenching. Tempering treatment also increases wear resistance, but if the tempering temperature gets higher it will reduce the wear resistance as the violence gradually decreases. The highest wear resistance after the specimen was quenchingtempering at $200^{\circ} \mathrm{C}$ (up $88 \%$ compared to as cast).

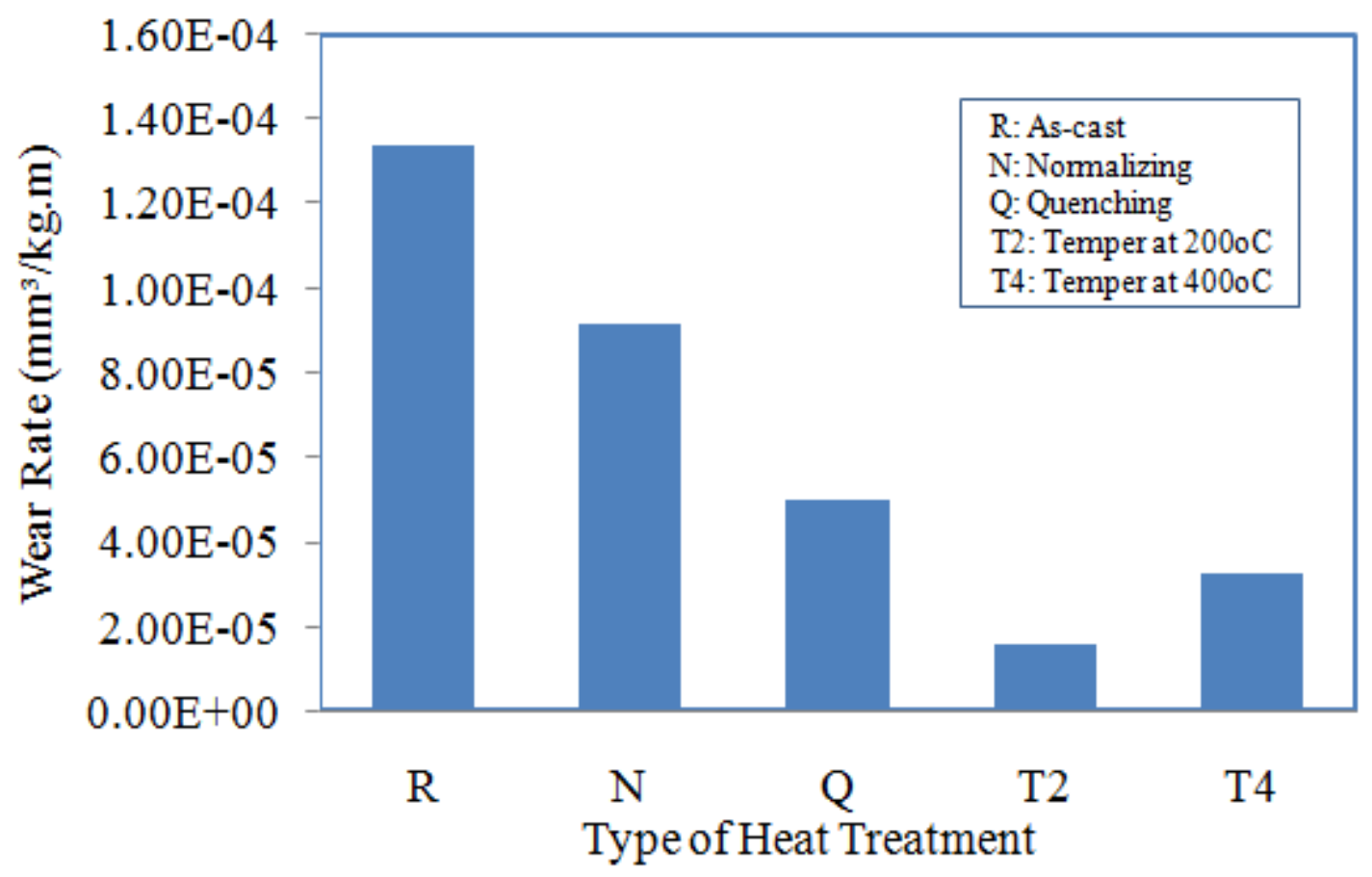

Fig 4: Wear Rate 


\section{ACKNOWLEDGEMENT}

We thank the DPP for funding our research. I hope this research can be utilized for industries, especially the metal casting industry.

\section{CONCLUSION}

After conducting research with various mechanical tests, conclusions can be drawn. They are:

1. The materials used are austenitic cast iron (Ni-resist) with the main alloy $17 \% \mathrm{Ni} ; 3,06 \% \mathrm{C} ; 2,77 \% \mathrm{Si}$ and $2,13 \% \mathrm{Cr}$.

2. The wear rate of the as cast is $1,34 \mathrm{E}-05 \mathrm{~mm}^{3} / \mathrm{kg} . \mathrm{m}$. Heat treatment increases wear resistance by $31 \%$ (normalising), 63\% (quenching) and $41 \%$ (tempering $200^{\circ} \mathrm{C}$ ) compared to as cast.

3. The corrosion rate of the as cast is 9,67E-05 $\mathrm{mm}^{3} / \mathrm{kg}$.m. Heat treatment increases wear resistance by $5 \%$ (normalising), 19,6\% (quenching) and $41 \%$ (tempering $200^{\circ} \mathrm{C}$ ) compared to as cast. Increased corrosion and wear resistance occur due to changes in microstructure and graphite size.

4. The corrosion rate of the as cast is 9,15E-5 mpy. Heat treatment decreases corrosion rate by $38 \%$ (normalizing), 52\% (quenching), 29\% (tempering $200^{\circ} \mathrm{C}$ ) and $14 \%$ (tempering $400^{\circ} \mathrm{C}$ ) compared to as cast.

\section{REFERENCES}

[1] Podrzucki, C. 1991. Cast iron, Structure, Properties and Application. T 2. Kraków: Ed. by ZG STOP, hal. 301- 303.

[2] Medyński, D., dan Janus, A. 2016. Effect of Austenite Transformation on Abrasive Wear and Corrosion Resistance of Spheroidal Ni-Mn-Cu Cast Iron. Published quarterly as the organ of the Foundry Commission of the Polish Academy of Sciences, vol. 16.

[3] Abadi, A., dan Shamloo, R. 2001. Control of Austenitic Transformation in Ductile Iron Aided by Calculation of Fe-C-Si-X Phase Boundaries. Journal of Phase Equilibria, Vol. 22(3), hal.194-198.

[4] Pietrowski, S., dan Gumienny, G. 2009. Obtaining Bainite In Castings Of Spheroidal Cast Iron With Carbides. Materials of 50th International Scientific Conference Solidification and Crystallisation of Metals. Kielce-Cedzyna.

[5] ASTM A436 - 84. 2015. Standard Specification for Austenitic Gray Iron Castings.

[6] Pietrowski, S. dan Bajerski, Z. 2005. Ni-Resist Cast Iron With Reduced Nickel Concentration. Archives of Foundry. Vol. 5(17), hal. 445-458.

[7] Tabor, A., Putyra, P., Zarębski, K. dan Maguda, T. 2009. Austenitic ductile iron for low temperature. Applications. Archives of Foundry Engineering, vol 9(1), hal. 163-168.
[8] Janus, A., dan Kaczmar, J.W. 1999. Nickel Equivalent In Austenitic Ni-Mn-Cu Cast Iron. Acta Metall Slovaca. Vol. 5(2), hal. 452- 457.

[9] Liu, Y.Z., Sun, L., Li, C.A, dan Wang, Y.F. 2012. Corrosion And Wear Behavior Of Nickel Austenitic Cast Iron. Journal of Central South University (Science and Technology) vol. 43(10).

[10] Heine, R.W., dan Loper, C. R. 1969. AFS Trans., hal.185-191.

[11] Dio' szegi, A., Liu, K.Z., dan Svensson, I.L. 2007. Inoculation of Primary Austenite In Grey Cast Iron. International Journal of Cast Metals Research, Vol. 20.

[12] Li, D., dan Sloss, C. 2015. Heat Treatment of HeatResistant Ferrous Cast Alloys. International Jurnal of Metalcasting, Vol. 9. 